\title{
DÜBLIN
}

Technological University Dublin

ARROW@TU Dublin

2004-01-01

\section{Child Sexual Abuse in Sub-Saharan Africa: a Literature Review}

\author{
Kevin Lalor \\ Technological University Dublin, kevin.lalor@tudublin.ie
}

Follow this and additional works at: https://arrow.tudublin.ie/aaschsslarts

Part of the Psychology Commons

\section{Recommended Citation}

Lalor, Kevin:Child Sexual Abuse in Sub-Saharan Africa: a Literature Review,Lalor, Child Abuse and Neglect, Vol. 28, pp. 439-460, 2004. doi:10.1016/j.chiabu.2003.07.005

This Article is brought to you for free and open access by the Social Sciences at ARROW@TU Dublin. It has been accepted for inclusion in Articles by an authorized administrator of ARROW@TU Dublin. For more information, please contact arrow.admin@tudublin.ie, aisling.coyne@tudublin.ie,gerard.connolly@tudublin.ie.

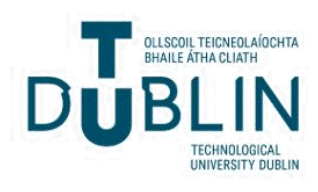




\section{CHILD SEXUAL ABUSE IN SUB-SAHARAN AFRICA: A LITERATURE REVIEW}

INTRODUCTION

Recent years have seen growing concern about the commercial sexual exploitation of children (CSEC) in the Developing World. That is,

"the sexual exploitation of a child for remuneration in cash or kind, usually but not always organised by an intermediary (parent, family member, procurer, teacher and so on)" (Muntabhorn, 1992).

CSEC may take the form of juvenile prostitution, child pornography, trafficking of children for sexual purposes and child marriages. Concern originally emerged regarding the involvement of minors in 'sex tourism' in South East Asia, particularly in Thailand and the Philippines, culminating in a global conference against CSEC in Stockholm in 1996. A second World Congress Against Commercial Sexual Exploitation of Children was held in Yokohama in December 2001. Also, the inclusion of juvenile prostitution as one of the Worst Forms of Child Labour in International Labour Organisation (ILO) Convention 182 has greatly facilitated the focus on this form of child abuse.

However, the focus on CSEC in the Developing World has meant that the more pervasive sexual abuse of children in their own homes, neighbourhoods and communities, frequently at the hands of peers, teachers, parents and other relatives has been neglected. A 1996 Eastern and Southern African Regional Consultation on CSEC (a preparatory consultative meeting for the First World Congress against CSEC), observed that, "apart from commercial sexual abuse of children, there were more alarming occurrences of the non-commercial sexual abuse of children in the form of domestic violence and incest ... far more attention needs to be paid to abuse in the home as both a primary cause of commercial sexual exploitation and as a far more serious problem in itself" (Unicef \& ANNPCAN, 2001, p. 8). 
More recently, a briefing paper for the $2^{\text {nd }}$ World Congress against CSEC reported that neither CSEC, nor child sexual abuse in the home/community, can be easily quantified in sub-Saharan Africa (SSA) due to a lack of adequate data and that CSEC cannot be analysed in isolation from the broader problems of sexual abuse and sexual exploitation:

"there is an overwhelming amount of anecdotal evidence that the problem of sexual abuse and sexual exploitation (including commercial sexual exploitation) of children in the region is an extensive problem. Children are sexually abused and exploited in the home, school, community, in the workplace and brothels. It is also clear that the HIV/AIDS pandemic is both a cause and consequence of sexual exploitation of children in the region" (Unicef \& ANNPCAN, 2001, p. 3).

Why has the sexual abuse of children in their own homes/communities not received wider attention in SSA? First, there is a widespread belief that it is a recent phenomenon, which can be attributed to the insidious forces of modernity, 'foreign influences' and rapid social change. Anecdotally, it is deemed to be 'un-African,' 'unnatural' and very rare. Of course, child sexual abuse occurs globally and no society is immune. Finkelhor (1994) aimed to illustrate the international epidemiology of child sexual abuse and found that research studies in 19 countries produced findings similar to North American research (prevalence ranging from 7-36 \% for women and 3-29\% for men), thus undermining the assumption of North American exceptionalism. He concludes

"Studies from a variety of countries suggest that sexual abuse [of children] is indeed an international problem. In every locale where it has been sought, researchers have demonstrated its existence at levels high enough to be detected through surveys of a few hundred adults in the general population ... As such epidemiological findings are available for more and more countries, the responsibility of proof shifts to anyone who would argue that sexual abuse is rare or nonexistent in their locale" (1994, p. 412). 
A second reason that the sexual abuse of children may not have received more attention in SSA is the range of competing social problems affecting children, such as war, disease, poverty, hunger and homelessness. Lachman (1996) suggests the paucity of research is due to lack of resources, the overshadowing of child protection by political and economic problems and the lack of a research culture and research experience.

A growing awareness of the extent of child sexual abuse can be detected in the media in this region, but empirical, peer-reviewed work is rare (with the notable exception of South Africa). This paper shall review the English-language, peer-reviewed literature relating to the sexual abuse of children, as cited in the Social Sciences Citation Index (SSCI). It shall also examine the Non-Governmental Organisation (NGO) and United Nations (UN) literature that has focused (largely) on the commercial sexual exploitation of children (for example, UNICEF, 1999; Human Rights Watch, 2001; International Labour Organisation, 2001; UNICEF \& ANNPCAN, 2001; UNHCR \& SC-UK, 2002). Finally, part of this paper shall be an examination of the primary causes of child sexual abuse in SSA, as reported in the literature, including rapid social change, human immunodeficiency virus (HIV) avoidance strategies and male-dominated social structures.

\section{CHILD SEXUAL ABUSE IN SUB-SAHARAN AFRICA}

Peer-reviewed research on the sexual abuse of children in sub-Saharan Africa (SSA) is limited and is largely confined to the Republic of South Africa. Ennew, Gopal, Heeran and Montgomery (1996), for example, noted that two recent annotated bibliographies of studies of African children and childhood (Gueye, 1995; Ross, 1995) provide no references to published work on sexual abuse. They conclude

"In terms of academic discourse, or even within NGO [non-governmental organisations] and IGO [international governmental organisations] literature, the topic of child sexual exploitation in SubSaharan Africa consists of an almost total vacuum, in which dispersed and disconnected items of journalistic and project-oriented text are floating aimlessly" (Ennew et al., 1996). 
The extant literature is reviewed below. After a brief discussion of some early studies, the remaining work is organised on the basis of (a) those using clinical samples and (b) those using non-clinical samples.

Early work (the 1980s)

In an early study of child abuse in the region, Fraser and Kilbride (1980) describe three cases of physical abuse among the Samia of Kenya. The sexual abuse of children is not reported in this paper. In another early study, Loening (1981) details the physical and emotional abuse and neglect of children amongst the Zulus of South Africa. No evidence of the sexual abuse of children was encountered in this hospital-based study. As the author notes, "in a society where the absolute taboo of incest includes sexual contact between any blood relatives, it is unlikely that this, the most shameful of misdemeanours, would come to light readily" (1981, p. 6). LeVine and LeVine (1981) did note the sexual abuse of young girls in their anthropological studies of the Gusii in Kenya:

"Sexual molestation of girls is a known phenomenon in tropical Africa. Among the Gusii we have encountered cases, for example, of rape of prepubescent girls by adult men who in many instances are the classificatory fathers of their victims (i.e., they are closely related members of their victims' parents' generation). We have also come across actual father-daughter incest. In addition, the seduction of pubescent girls by male schoolteachers is the occasion for recurrent scandals in Nigeria and Kenya" (LeVine \& LeVine, 1981, p. 38).

Okeahialam's (1984) study of child abuse in Nigeria also focused on physical forms of child abuse such as excessive corporal punishment, infanticide and female circumcision. Again, the sexual abuse of children was not addressed.

Research using clinical samples 
In one of the earliest studies to examine child sexual abuse in SSA, Westcott (1984) describes 18 cases seen at the Red Cross War Memorial Children's Hospital in Cape Town over a 6-month period in 1982. Victims ranged in age from 2 to 12 years, and the majority (80\%) were female. The majority of victims were Coloured (65\%), the remainder being Black, in keeping with the general hospital population (the terms Coloured, White, Black, Asian were used to categorise all South Africans during the Apartheid era and their usage is commonplace in the South African literature; a Coloured person is one of mixed White and non-White descent). In over half of the cases, the offender was a relative, a neighbour or a friend of the family.

A second early study of child sexual abuse in South Africa (Jaffe \& Roux, 1988) examined 88 cases in the same Children's Hospital. The authors note the increased numbers of sexually abused children presenting at this hospital: 18 recorded over 6 months in 1982 (Westcott, 1984) and 88 recorded over 12 months in 1985 (Jaffe \& Roux, 1988). Of these 88 children, 90\% were female and most were in the 4 to 6 year old age group. In $57 \%$ of cases, the perpetrator was known to the victim. The largest category of perpetrator (16) was that of a neighbour, followed by father (14). The authors conclude by noting the limited generalisability of clinical studies and by calling for community-based studies of sexual and physical abuse in South Africa.

Haffejee (1991) described 37 cases (34 females and three males) of child sexual abuse detected over a 6year period in a hospital in Durban. Perhaps reflecting the clinical nature of this sample, a majority of these children had experienced vaginal or anal intercourse. Of the 35 perpetrators identified, the majority (23, $67 \%$ ) were well known to the child - fathers, stepfathers or uncles. Seven (18.9\%) were strangers. Ten of the 35 children were found to have a sexually transmitted disease (eight had gonorrhoea and two syphilis). No screening for AIDS took place.

This study was important in highlighting the existence of child sexual abuse in a population (South African Indians) where it had not previously been recognised. In the author's words, "sexual abuse has been 
identified and documented in a community in which it was previously thought to be non-existent" (Haffejee, 1991, p. 150).

A further 229 cases of child sexual abuse in a Children's Hospital in Cape Town were described by Argent, Bass, and Lachman (1995). These were the number of children under 15 years who presented at the hospital over a 12-month period. Their mean age was less than 7 years, and they were predominantly English/Afrikaans (58.7\%) and Xhosa (41.3\%). A large proportion of these children (17\%) had evidence of a sexually transmitted disease.

Larsen, Chapman, and Armstrong (1998) describe the work of a team at Eshowe Provincial Hospital, KwaZulu-Natal. Ninety-nine cases of child sexual abuse were encountered there between 1985 and 1995. The results from 91 of these cases are presented (87 females and 4 males). In many (34\%) cases, the perpetrator was not identified. The largest category of known perpetrators was 'neighbour/acquaintance' (41\%), with fathers accounting for about $6 \%$ of perpetrators and 'other family members' accounting for another $6 \%$ of perpetrators. Most worryingly, a large number of the children (65.9\%) were suffering from a sexually transmitted disease (STD), perhaps due to a family decision to turn to modern medicine because the child had a STD.

Research with clinical samples, while documenting the existence of the problem and providing descriptive data, does not provide prevalence information.

\section{Research using non-clinical samples}

As with the clinical studies described above, the majority of surveys of non-clinical samples were conducted in South Africa. Levett (1989) sampled a (slightly) more representative population than the previous hospital-based studies by surveying 94 female students of the 1986 second year psychology course at the University of Cape Town. The sample was predominantly White (78\%), with $22 \%$ Coloured women and no Black participants. Results indicated that $43.6 \%$ of the sample reported sexual abuse or 
harassment before age 18. Of these experiences, almost half (47.5\%) were forms of contact sexual abuse (the most common being unwanted touching), the remainder being non-contact (the most common being followed by men and exposure to an exhibitionist). Some $7.5 \%$ of the sample experienced a rape or attempted rape. Strangers were involved in $65.6 \%$ of all reported cases, relatives in $13.1 \%$, and the remaining $21.3 \%$ involved neighbours, teachers, friends of parents, romantic acquaintances and a friend of an older brother.

The absence of any report of incestuous experiences involving a close family member (such as father) or of any report of recurring experiences of abuse involving a single perpetrator, together with a rate of rape/attempted rape $(7.5 \%)$ which was perceived to be low, leads the author to speculate that the results constitute an under-estimation of the true occurrence of sexually abusive experiences in childhood. Levett (1989) does not examine risk factors or other explanations for the sexual abuse experienced by her sample.

Collings (1991) surveyed 284 male undergraduate psychology students at the University of Natal, with an average age of 19.7 years. Racially, this sample was more diverse than the previous study; $60.9 \%$ of the sample were White, $18.7 \%$ Asian, $16.2 \%$ Black and $4.2 \%$ Coloured. Some $28.9 \%$ of the sample reported experiences of child sexual abuse, with approximately two thirds of these incidents non-contact and one third a contact form.

The author notes that the overall prevalence rate of $28.9 \%$ is significantly higher than the $5 \%$ to $14 \%$ prevalence rates obtained in surveys of American college men and the $3 \%$ to $16 \%$ prevalence figure obtained in surveys of the general population of adult men in the United States. However, he later states that "after controlling for definitional and methodological sources of variation, the prevalence figures for the South African sample were similar to those obtained for American students" (1991, p. 156).

It is also interesting to note that only $67 \%$ of the perpetrators were male, illustrating a sizeable proportion of female sexual offenders of male children. Prevalence rates varied by ethnicity, with Black respondents significantly more likely to report abusive sexual experiences in childhood $(54.5 \%)$, relative to Whites 
(26.3\%), Coloureds (33.3\%) or Asians (32.1\%). Indeed, race (that is, being Black) is reported as the most powerful predictor for abuse, although the author does note that the sample of Black students $(n=46)$ is small and that this finding should be treated with caution. The author offers no other explanation for this racial variance. Being raised without one's father for a significant portion of one's childhood is also identified as a risk factor. Whilst not explicitly discussed by Collings (1991), the widespread practice of migratory workers in South Africa may play a role in increasing risk amongst Black boys.

Collings (1997), of the University of Natal's Child Abuse Research Unit, conducted the largest study of its kind in the region. He surveyed a sample of 640 female university students regarding their unwanted sexual experiences involving physical contact experienced whilst a child of 17 years or younger. The sample was $64 \%$ White, $21 \%$ Asian, $11 \%$ Black, but a breakdown of abuse by ethnicity is not provided. Results indicate that 223 (34.8 per cent) of the total sample experienced contact sexual abuse before the age of 18 years (Table 1$)$.

The author notes that these prevalence figures are comparable with those obtained in studies of the general population of adult women in the US (Russell, 1986), Canada (Badgley et al., 1984) and New Zealand (Martin, 1994), but considerably higher than the $7 \%$ to $24 \%$ prevalence rate obtained in studies of American college women (for example, Bergner, Delgardo, and Graybill, 1994; Briere \& Runtz, 1985; Finkelhor, 1979).

Perpetrators were typically (over $70 \%$ ) at least 4 years older than respondents and the overwhelming majority $(93 \%)$ were male. They were primarily acquaintances $(40.4 \%)$, strangers $(28.7 \%)$ and relatives $(22.7 \%)$. Stepparents constituted $3.9 \%$ of perpetrators and biological parents $4.3 \%$.

Targeting a more representative sample than University students, Madu and Peltzer (2000; 2001) surveyed 414 secondary school students from the Northern Province, South Africa (ages 14 to 30 years) with a mean age of 18.5 years regarding their experiences of contact sexual abuse before the age of 18, with "an adult or person at least five years older than the child or a person in a position of power." A very high prevalence 
rate of $54 \%$ of the total sample reported experiencing contact sexual abuse before the age of 18 years. Unusually, the prevalence rates for males and females are similar (60\% and 53.2\% respectively). Prevalence rates for all ethnic groups are high, as shown in Table 2.

Sixty five of the 414 respondents $(15.7 \%)$ had experienced oral, anal, or vaginal intercourse or had fingers or objects placed in their anus or vagina. Sixteen (3.86\%) indicated that the sexual intercourse was done by force. The authors attribute this abuse to absent parents (migrant workers), high numbers of stepfathers, unaccompanied or street children, and poverty (enabling entrapment of children with the lure of gifts):

"In this province, many parents work as migrant labourers - either in other provinces or at places far away from their homes. As a result, many children are left either alone at home during the weekdays after school or with nannies and grandparents, who may not give them proper care. Thus, they are vulnerable to sexual abuse from opportunistic predators" (Madu \& Peltzer, 2001, p. 318).

The high prevalence rate amongst males $(60 \%)$ could be due to the absence "of the adult male (who is working as a migrant labourer) in many families and the frequent single parenthood in the society [which] contributes to adult females abusing boys" (2001, p. 318).

Madu (2001) surveyed 722 University students (64\% female) in the University of the North, South Africa regarding their experiences of childhood sexual abuse, defined as experiences before the age of 17 with a person at least 5 years older, or a person in a position of power. The majority $(95.4 \%)$ of respondents were Black, with single figure numbers of other categories. Respondents $(\mathrm{N}=649)$ reported a prevalence for contact sexual abuse of $21.7 \%$ for males and $23.7 \%$ for females. As expected, the prevalence decreases as the 'seriousness' of the abuse increases (sexual kiss by force, 7.3\%; sexual touch by force, 5.2\%; oral/anal/vaginal intercourse by force, $4.5 \%$ ). 
Madu (2001) notes that these prevalence figures are lower than those reported in other South African studies and suggests that the rural location of the University of the North, in the Northern Province of South Africa, means lower levels of risk factors for child sexual abuse: that is, low substance abuse, high parental availability and high adherence to cultural values. It is interesting to note that the higher prevalence reported by Madu and Peltzer $(2000 ; 2001)$ amongst a sample of 414 secondary school students in the same geographic region was, in part, attributed to migrant labour and absentee parents. One must presume that parental availability is a function of socio-economic status whereby affluent University students (the sample in Madu, 2001) are less likely to experience migrant labour patterns in their families than a sample of secondary school students.

Cross-study comparisons

Comparisons across studies are difficult, due to the variety of terms and definitions used by authors. Below, a limited comparison of 'sexual kissing by force', 'sexual touching by force' and 'oral/anal/vaginal intercourse by force' across studies is made. Wider comparisons are not possible due to lack of consistency in definitions. Even in the material below, the reader's attention is drawn to variations in definition.

Table 3 allows some tentative comparisons. Although differing definitions of sexual abuse are used (particularly the variation in whether experiences below age 18 or 17 are studied) and differing operationalisations are employed (for instance, 'sexual touching by force', 'unwanted genital fondling', 'unwanted sexual touching' and 'kissing, stroking or touching'), some common trends emerge.

Specifically, between $3.2 \%$ and $7.1 \%$ of all respondents report experiencing unwanted or forced sexual intercourse as a child. Only one study (Madu, 2001) allows a male/female comparison; females report a higher prevalence of penetrative child sexual abuse. Large variations are reported in the prevalence of nonpenetrative sexual abuse. For instance, Madu and Peltzer $(2000 ; 2001)$ report that approximately $10 \%$ of respondents experienced sexual touching by force during childhood. Other studies report much higher levels; Collings (1997) reports prevalence levels of $26.3 \%$ of unwanted genital fondling amongst a sample 
of female University students. Levett's (1989) high prevalence level of $36.1 \%$ is no doubt a function of the wider definition employed in that study; that is, being kissed stroked or touched intrusively (on genitals, buttocks or breasts) in a sexual way against your will before age 18 .

Cross-study comparisons are a central feature of any literature review. However, it is not yet possible to make thorough comparisons between studies of child sexual abuse in sub-Saharan Africa as only a small numbers of studies have been conducted, and these have utilised a variety of definitions and operationalisations that make comparison difficult.

\section{Other regional studies}

A small number of studies have been conducted outside South Africa.

Meursing et al. (1995) employed a variety of strategies to research the nature of child sexual abuse in Zimbabwe; record review, structured interviews with child protection professionals and focus groups. This comprehensive approach elicited a variety of data, from disparate sources. For example,

“A rural mission hospital examined 324 rape cases between 1983 and 1990, of who 43\% was under 16 and 9\% under 12 years old ... The Bulawayo Regional Court dealt with 67 cases of child sexual abuse in 1981, 87 in 1986 and 122 in 1991” (Meursing et al., 1995, p. 1696).

Rape cases at seven major police stations in Bulawayo were also collated. Table 4 below illustrates that a considerable amount of child rape occurs in this city. In total, Meursing et al. provide an age breakdown of 1,025 rape victims in Bulawayo between 1985 and 1991 and 38\% are 15 years of age or younger. No further data pertaining to these incidents is reported. 
Given the dearth of data on child sexual abuse in SSA, the multi-method approach adopted by Meursing et al. (1995) is an effective way of gathering initial data on the nature of the problem, which is so important in creating initial public awareness.

Armstrong (1998) investigated 36 cases of child sexual abuse amongst the Shona of Zimbabwe, largely from a legal perspective. She describes the remedies enacted by families to compensate them for the rape of a girl-child; for example, the payment of fines or (in 8 of the 36 cases) the marrying of the rapist and victim to fulfil the girl's lobola (bride price). She notes that "a girl who has had sexual intercourse, whether consensual or not, has less chance of contracting a marriage that will contribute lobola to the family. Thus, the sexual abuse of a girl has grave economic consequences for the family" (1998, p. 144). The focus of this research is on the relationship between the informal (tribal) and formal (legal) remedies used by families to deal with the sexual abuse of a girl-child. As such, the demographic, familial and psychological particulars of the 36 cases are not examined systematically. However, two cases of grandfathers raping their granddaughters and two further cases of men raping the niece of their wives are recorded.

Lema (1997) describes 20 cases of child sexual abuse that presented at the Department of Obstetrics and Gynaecology, University of Malawi between 1995 and 1997. Half were less than 10 years old. Lema estimates that these cases are merely the tip of the iceberg, and were reported due to the serious injury caused in the rape of very young children.

A recent (interim) report by UNHCR and Save the Children-UK in Guinea, Liberia and Sierra Leone revealed alarming levels of sexual violence and exploitation of refugee children (UNHCR \& SC-UK, 2002). This investigation is ongoing, but allegations have been made against UN peacekeeping forces, international and local NGOs and government agencies responsible for humanitarian response. Most of the allegations involved male national staff, trading humanitarian commodities and services, in exchange for sex with girls under 18. The children most vulnerable to sexual exploitation were those without the care of their parents, children in child headed households, orphaned children, children in foster care, children 
living with extended family members and children living with just one parent. A number of the men interviewed believed that sex with a virgin could cleanse a man from infection.

\section{AIDS/HIV as a Stimulus to Research on Human Sexuality}

Considerable research has been undertaken to understand sexual knowledge, behaviour and attitudes in SSA to assist public awareness and public health education campaigns. An early literature review of sexual behaviour in SSA was Standing and Kisekka's (1989) annotated bibliography that was "intended as a contribution to basic research on AIDS transmission and to the formulation of appropriate prevention programmes" (p. i). What is most remarkable about this review of hundreds of medical and anthropological papers on sexual behaviour in SSA is the dearth of material on child sexual abuse except for two studies noted below.

Kisekka and Otesanya (1988) examined STD (including AIDS) prevalence amongst 961 patients in Nigeria. Of the females identified as having a STD $(\mathrm{N}=163), 16 \%$ were aged less than 5 years and a further 6\% were aged less than 15 years. The writers infer that such high prevalence rates for STDs amongst female children suggest child sexual abuse and very early coitus amongst schoolchildren. However, no details are provided as to the nature of the STDs. If it were predominantly AIDS/HIV, maternal transmission at birth or during breast-feeding may also be an explanation.

A study from Lagos, Nigeria (Emmaneul, 1975) details 105 paediatric gynaecological cases examined between 1963 and 1973. Twenty cases were described as being caused by 'sexual interference', mostly by older men.

More recently, a major international effort to study sexual behaviour (with a view to better understanding the spread of AIDS/HIV) was the World Health Organisation's GPA (Global Programme on AIDS) series of surveys on knowledge, behaviour and attitudes to AIDS. Caraël (1995) details the WHO/GPA findings 
on sexual behaviour in the developing world and, whilst an extensive array of sexual behaviours is described, child sexual abuse is not mentioned.

In conclusion, the HIV/AIDS pandemic in SSA has led to an increase in research on sexual behaviour. However, thus far, this new literature on sexual behaviour does not contribute significantly to the knowledge on child sexual abuse in sub-Saharan Africa.

Sexual exploitation of school girls and the 'sugar-daddy' phenomenon

Finally, while not a focus of this paper, we should note the widespread concern in the region regarding the levels of sexual exploitation and assaults against schoolgirls by male pupils and teachers. This has been documented in South Africa by Human Rights Watch (2001). In three provinces visited by Human Rights Watch, cases of rape, assault and sexual harassment of girls committed by teachers and male students were documented. Girls were fondled, raped in school toilets, empty classrooms, hallways and in hostels and dormitories. The reader is also referred to Mgalla, Schapink, and Boerma (1998).

A further issue of concern is the involvement of adolescent girls in relationships with older, wealthier men, frequently referred to as the 'sugar daddy' phenomenon. Writing of Cameroon, Calvès, Cornwell, and Enyegue (1996) describe the context of this behaviour:

"The exchange of gifts between lovers is a cultural norm in Cameroon (at least in Yaoundé and in the East). Sex is perceived as an activity where the woman gives and the man receives. The male lover is then seen as a debtor and he is expected to support his partner or to provide her with food, gifts, or money, in return for her sexual services (p. 7).

For poor adolescents, such relationships may be a source of food, shelter or school fees, but it is also found among university students or the children of white collar workers to finance expensive items such as clothes, jewellery, books and so on. 
Barker and Rich (1992) conducted focus group discussions with adolescents regarding sexuality. On the issue of 'sugar daddies' and 'sugar mommies',

"Female students in Zaria mentioned that because of the current economic situation in Nigeria, women who live far from school are frequently forced to accept rides from men and then find themselves in the 'owing position.' When school fees were recently raised, they said, some girls went out looking for sugar daddies to help pay for them" (p. 207).

A number of studies have noted the higher incidence of HIV amongst adolescent females, relative to males

in SSA. Two population-based surveys in areas of Tanzania and Uganda revealed that $13-17 \%$ of females aged 15-24 were HIV-positive, compared to only 5\% of males in the same age group (Borongo, Borgdorff, Mosha, Nicoll, Grosskurth, Senkoro, Newell, Changalucha, Klokke, Killewo, Velema, Hayes, Dunn, Muller, \& Rugemalila, 1992; Nunn, Kengeya-Kayondo, Malamba, Seeley, \& Mulder, 1994, cited in Mensch, Bruce, \& Greene, 1998). This is explained by the tendency for adolescent girls to become involved in sexual relations with older adolescents and young adults, more so than adolescent males.

\section{EXPLANATIONS FOR CHILD SEXUAL ABUSE IN SUB-SAHARAN AFRICA}

Explanations for the sexual abuse of children in SSA may be grouped into three categories; rapid social change, a STD/HIV avoidance strategy and a male-dominated social structure:

\section{Rapid Social Change}

A conclusion shared by a number of studies is that child sexual abuse is on the increase in SSA. Fraser and Kilbride (1980, p. 231) suggest that "child abuse and neglect are associated with a disintegration of clan authority occasioned by such factors as interethnic marriage, migration into towns and other modern social and economic forces." Loening (1981) attributes the increase in child abuse to a breakdown of the 
traditional culture, due to rapid and radical social change. Okeahialam (1984, p. 69) also notes the perception that child abuse in Africa is a product of modernisation and that it did not previously exist:

"There is an impression that child abuse does not occur in the traditional African society. This is fostered by the sociological concept of the extended family as a system which provides profound love, protection, security and care to the child within the cultural milieu."

Jinadu (1986), too, claims that "child abuse and neglect in the developing African countries are ... devastating consequences of rapid socio-economic changes on the families" (p. 115).

Haffejee (1991) suggests that child sexual abuse is a recent phenomenon amongst the Asian community in South Africa, due to social and cultural change. However, he acknowledges there is little scientific data to support this view. Larsen, Chapman, and Armstrong (1998, p. 263) describe child sexual abuse as a "significant problem" in rural societies in South Africa. Again, social breakdown (specifically, the migratory labour system and rapid urbanisation) is implicated.

Lema (1997, p. 743), too, comments that "over the past one to two decades there has been an escalating wave of sexual abuse of young girls [in sub-Saharan Africa] ... The situation appears to have a taken a dramatic turn for the worst over the past five years or so in Malawi." Lema acknowledges that there are no reliable medical or legal records to support this claim.

Thus, the view that child abuse (including sexual abuse) is a recent phenomenon in SSA has widespread currency. Are such assumptions valid? Firstly, comparisons between the present and the past are difficult because of the lack of accurate (any) records regarding child welfare in the past. Thus, comparisons between the present and the past must be acknowledged as speculative and anecdotal. This being said, the idea that child abuse (sexual and otherwise) is attributable to rapid social change and modernity is not implausible. Socio-economic and socio-cultural change have been linked with an increase in child maltreatment (Korbin, 1991). Such increases are often attributed to a breakdown in traditional values and 
practices. Immigrant and urbanising families, for example, face unique problems that may potentially lead to child mal-treatment. Through formal schooling, immigrant children acquire more knowledge of the new environment than their parents and become less compliant and obedient, providing greater opportunities for parent-child conflict (LeVine \& LeVine, 1985, cited in Korbin, 1991). The move from rural to urban areas may isolate families from kin and social networks, thereby decreasing the likelihood that parent-child conflict can be diminished before it escalates to maltreatment (Ritchie \& Ritchie, 1981, cited in Korbin, 1991). A further explanation for the apparently higher occurrence of child sexual abuse in modern societies focuses on social fragmentation. According to this view, child sexual abuse is due to the increasing isolation of individuals and families from a sense of community; the result of increased mobility and the disintegration of neighbourhoods, communities and kin networks. This isolation facilitates child sexual abuse as it deprives people of socially sanctioned forms of support and intimacy, so they turn instead to forms that are taboo. Finkelhor (1979) noted that the socially isolated family is much associated with incestuous behaviour. Such families shy away from social interaction and draw in upon themselves. Thus, sexual attachments that would ordinarily develop outside the family occur within the family (Finkelhor, 1979, p. 30).

This being said, however plausible the idea that rapid social change may contribute to an increase in child maltreatment, it is nevertheless the case that such claims are usually unsubstantiated in the SSA context. Child sexual abuse has been recorded, historically, in 'traditional' extended-family based societies; in early-Christian Ireland (Lalor, 2001) and the Byzantine Empire (Lascaratos \& Poulakou-Rebelakou, 2000), for example. Why should it not also have occurred in African societies in the past? It might be reassuring to imagine that child sexual abuse is a recent phenomenon, attributable to modern, Western values, but there is very little evidence for (or against) this widely held view.

Furthermore, the rise of reported occurrences of child sexual abuse in the US and Europe in recent decades is rarely attributed to dramatic social change or fragmentation (and, whilst perhaps not as dramatic as changes in SSA, many regions in other areas of the World have undergone substantial social, economic and lifestyle changes in recent decades). Instead, authors refer to the previous lack of knowledge amongst child 
protection professionals and society in general (Korbin, 1987; Lalor, 2001) and the lack of child protection structures to detect, record and treat child abuse victims.

\section{Child Sexual Abuse as a STD/HIV Avoidance Strategy}

A further feature of the African literature we have examined is the frequently cited perception that child sexual abuse may, in part, be explained by beliefs in the 'cleansing' nature of sex with virgins and young girls. That is, sexual intercourse with children may cure one of disease, or in other ways bring good fortune or financial success. Meursing et al. (1995), writing of Zimbabwe, claim

"It is widely known that some traditional healers advise clients seeking luck in farming, business, gambling or other monetary affairs, to secure this luck by having sex with very young girls, often the client's own daughter" (Meursing et al., 1995, p. 1694).

No empirical evidence is provided. Lema (1997, p. 745) writes:

"The scare of HIV infection and AIDS ... is thought to be a major contributing factor to the increase in sexual assaults of young girls, who are considered to be relatively free of the infection. There are also beliefs in some areas of sub-Saharan Africa, that having sex with a young virgin girl may cure sexually transmitted diseases such as gonorrhoea. Stories are also told to the effect that some local medicine-men prescribe sexual intercourse with young prepubertal or immediate post pubertal daughters as remedy to men seeking advise on ways to get rich quickly and retain the wealth. In the latter case it [is] said that the man's wife prepares her daughter for sexual intercourse with her father! It is not certain though if and to what extent these are practiced in Malawi."

The author acknowledges that evidence is only anecdotal and that further research on this topic is required. 
Madu \& Peltzer (2000) also speculate that a major contributing factor to the increase in sexual assaults on young girls/virgins in sub-Saharan Africa is the belief that such females are less likely to be infected with the HIV virus. Citing Lema (1997), they report that, in some areas, it is believed that such intercourse will actually cure STDs. Thus, Lema's speculation reappears in Madu \& Peltzer (2000). So long as the lack of empirical evidence is acknowledged, this is quite valid. However, there is the danger that this secondary and tertiary citing of unsubstantiated anecdote will lead to an undeserved credibility for the position held.

Is there any evidence that children are sexually targeted as an STD/AIDS avoidance strategy? Meursing et al. (1995) conducted focus groups with a sample of traditional healers on the issue of child sexual abuse in Zimbabwe. Conflicting views emerged:

"Male traditional healers deny advising men with STDs to have sex with a virgin in order to get 'cleansed'. However, females healers state that their male counterparts are involved in such practices, and further indications of the existence of such practices were found when a focus group participant told the group that her sister's nine-year old daughter became HIV positive when she was given to her uncle to 'cleanse' himself from HIV and STDs” (Meursing et al., 1995, p. 1697).

The authors conclude by saying: "The use of sex with young girls as a 'cleansing' method for HIV and STD needs more investigation, but during this study two cases were reported of young girls who became infected with HIV and STD because of 'cleansing' practices, making it likely that this practice is more widespread" (Meursing et al., 1995, p. 1703).

The 1998 Demographic and Health Survey (DHS) in Kenya asked 1,827 women and 805 men about ways to avoid AIDS (National Council for Population and Development (NCPD), Central Bureau of Statistics (CBS) (Office of the Vice President and Ministry of Planning and National Development) [Kenya], and Macro International (MI), 1999). Eight percent of both women and men reported a means that reflects disinformation, such as avoiding mosquito bites, seeking care from a traditional healer, or spiritual intervention. What proportion of this is made up of beliefs in the power of sex with a virgin, as 
recommended by traditional healers, is not reported. Perhaps surprisingly, for both men and women, levels of misinformation are positively correlated with education. For women, $4.6 \%$ of women with no education held such beliefs, increasing to $12 \%$ for women with at least a Secondary education. For men, $3.9 \%$ with no education hold such beliefs, increasing to $10.8 \%$ for men with at least a Secondary education.

A sample of 54 adults in Tanzania (Unicef, 1999) were asked why adults might have a preference for juvenile prostitutes. Thirteen respondents (four men and nine women) agreed that it is because children do not have AIDS. On the other hand, 29 respondents (15 men and 14 women) agreed that it was to 'increase the variety' of their sexual lives. Another factor considered important was the cheaper rate charged by children. The researchers conclude that "the supposed myth that children are targeted for sex as a means of avoiding/curing AIDS is by no means universally held in Tanzania” (Unicef, 1999).

To conclude, the idea that child sexual abuse (or the demand for younger prostitutes) is a STD/HIV avoidance strategy has widespread currency. Whilst it may be the case, it has not been satisfactorily investigated or substantiated.

\section{A Male-Dominated Social Structure}

A further explanation for child sexual abuse (and sexual assaults generally) in SSA is the male-dominated nature of society. A common theme is the 'uncontrollability' of male sexual urges and the role of physical force in sexual relations. Buzzard (1982) notes the strongly held ideology in Kisumu, Kenya that men must have access to sex constantly. Men are also viewed by women as morally weak and lacking in self-control in relation to sex. Nelson (1987) makes similar observations of the Kikuyu of Kenya:

\footnotetext{
"Kikuyu understandings of male sexuality by both men and women concur in considering the male sex drive to be strong and in the view that men need both a great deal of sex and variety in their sexual partners. Men, additionally, appear to view the satisfaction of sexual need with several partners as a right deriving from the tradition of polygyny. While polygyny is declining
} 
for economic reasons, men have redefined it in terms of rights to regular sexual liaisons with lovers/mistresses, combined with one legally married wife" (Nelson, 1987, cited in Standing \& Kisekka, 1989, p. 102).

Similar issues were explored in Zimbabwe, using a series of focus groups. It was reported that:

"men and women [focus group participants] seem to agree that if a man feels sexually excited, he must find a way to release his sexual tensions. Masturbation is culturally not seen as an option for an adult man. If he does not succeed to find a partner (maybe because he has no money to entice a girlfriend, or the girl is 'stingy' with her favours and refuses sex, or because his wife is away) he can be 'forced by his nature' to rape” (Meursing et al., 1995, p. 1697).

The focus groups revealed divided views on the rape of teenage girls, especially amongst men:

"Respondents consider male lust to be the most common motive for the rape of a teenage girl, and say that some men prefer to have sex with young girls because they are 'tight' and can be easily duped or paid off with a few coins or a small gift. Many boys and men lay the responsibility for provoking lust squarely on the shoulders of the girl, while finding excuses for males succumbing to temptation. They give examples of girls who have 'brought it on themselves' by acting older than they were, lying about their age, or dressing in a seductive manner" (Meursing et al., 1995, p. 1697).

A further factor that may facilitate rape is the role of force in sexual relations:

"Another problem which surfaced during the focus group discussions is the communication about sex between men and women. Women are culturally obliged to say 'no' to sex even when they want it, and men generally see no problem in exercising some force when pressing for sex. These attitudes facilitate rape of women of any age. They are especially disturbing when considering 
relationships between older men and young girls, since young girls are traditionally bound to obey older men" (Meursing et al., 1995, p. 1697).

Thus, the sexual abuse of children may be facilitated by a widespread belief and cultural acceptance of the urgency of male sexual relief and a certain tolerance or expectancy of the use of physical coercion in sexual relations. Furthermore, the emphasis on children's obedience to adults and male supremacy over females allows men to yield a double authority over girls.

It is worth noting that these views were expressed in a small number of focus groups and cannot be considered representative of general beliefs and attitudes throughout Zimbabwe, let alone SSA.

Kaboberi-Macharia (1998, p. 52) suggests that incest is facilitated in Eastern and Southern Africa as a result of socialisation pressures to respect parents and elders. Armstrong (1998, p. 145), too, suggests that the African child's socialisation of obedience to elders heightens vulnerability to abuse. She suggests that "we need to find ways to combine the cultural norm of respect with a kind of autonomy that enables children to question their elders and their authority in appropriate circumstances."

The previously mentioned UNHCR/SC-UK report (2002) on the sexual exploitation of refugee children in West Africa also refers to the power disequilibrium amongst male Aid workers and female refugee children. The Assessment Team identifies poverty and lack of livelihood options for refugees as a principal contributing factor to their vulnerability to sexual exploitation. The involvement of children and women in sexually exploitative relationships has become a mechanism for survival for many refugee families. Insufficient food rations and widespread hunger in the camps encouraged girls to enter exploitative sexual relations to support their families. The Assessment Team did not assess the numbers of refugee children who became HIV positive as a result of sexual exploitation and violence. However, they note "all the indicators point to high risk behaviour patterns, which expose children to STD and HIV/AIDS infection. The combination of immature bodies, poverty, lack of negotiating powers and practices of unsafe sex, disbelief and HIV/AIDS are factors that increase the risk" (UNHCR and SC-UK, 2002, p. 12). 


\section{DISCUSSION}

Certain features of the available research on child sexual abuse in SSA are worth highlighting.

AIDS/HIV risk

The high risk of disease transmission as an outcome of child sexual abuse in SSA is of serious concern. The high incidence of AIDS/HIV in the general population (for example, 19.94\% of 15-49 year olds in South Africa; $25.06 \%$ of 15-49 year olds in Zimbabwe; 35.8\% of 15-49 year olds in Botswana) (UNAIDS/WHO, 2000) and the levels of penetrative sexual abuse of children reported in some studies expose children to high levels of risk.

For instance, a prevalence rate of five per cent for penetrative child sexual abuse, coupled with the high incidence of HIV in the region, brings considerable risk of infection for sexually abused children. Assuming that the perpetrators of penetrative sexual abuse against children are no more or less likely to have AIDS/HIV than the general population (and assuming that all perpetrators are aged 15-49), we can estimate that $1 \%$ of all children in South Africa will have experienced penetrative sexual abuse with an AIDS/HIV infected person by the time they are 18 years old (see Table 5). This estimate does not include consensual sexual activity that may occur before age 18 .

Should similar prevalence figures for penetrative child sexual abuse (that is, $5 \%$ ) be the case in other countries in the region, we can estimate that $1.25 \%$ of all children in Zimbabwe and $1.79 \%$ of all children in Botswana, will have experienced abusive penetrative sex with an AIDS/HIV infected person before age 18. 
In contrast, the comparable estimate for Ireland, for example, is $0.004 \%$ (based on $4.13 \%$ incidence of penetrative child sexual abuse amongst the general population (McGee, Garavan, de Barra, Byrne, and Conroy, 2002) and 0.1\% national incidence of Aids/HIV (UNAIDS/WHO, 2000).

Surprisingly, this issue has not yet received sufficient attention in the AIDS/HIV literature, nor in the child sexual abuse literature. A number of studies reported STD frequency levels amongst child sex abuse victims [Haffejee, 1991 (28.57\%); Argent, Bass, \& Lachman, 1995 (17\%); Larsen, Chapman, \& Armstrong, 1998 (65.9\%)], but none of these studies tested for AIDS/HIV.

Given the high prevalence levels of AIDS/HIV in the region, the potential infection of child sexual abuse victims with life-threatening diseases is a further likely sequela of child sexual abuse that has not been adequately appreciated in the region.

\section{Abuse by strangers}

A second trend of note is the proportion of child sexual abuse perpetrated by people known to the child. Not all epidemiological studies break down 'contact' abuse and 'non-contact' abuse by perpetrators. Thus, Levett (1989) reports that $65.6 \%$ of perpetrators are strangers. However, this includes 'being followed' and 'exposure to an exhibitionist.' For those studies that do report the perpetrators of contact sexual abuse, the proportion of offences committed by strangers is much lower; for instance, 9.9\% (Madu, 2001). A small number of studies identify the perpetrators of oral, anal or vaginal intercourse. Of these, 'strangers' are a small proportion of offenders; for instance, 7.7\% Madu \& Peltzer, 2000; 2001) and 5.3\% (Madu, 2001).

In other words, the perpetrators of non-penetrative contact sexual abuse and penetrative sexual abuse (oral, anal or vaginal intercourse) are more likely to be known to their victims; that is, family, neighbourhood or community members. This is noteworthy given the low levels of awareness in the region that child sexual abuse occurs in the home and family to a greater extent than it does in 'commercial sexual exploitation' contexts (for example, juvenile prostitution). 


\section{Abuse by professionals}

Recent research from South Africa shows unusually high incidences of abuse by professionals. For instance, Madu (2001) reports that, of a sample of 722 male and female undergraduate students of psychology, 57 experienced sexual intercourse before age 17 with an 'adult or person at least five years older or in a position of power over the child.' Of these 57 cases, seven perpetrators (12.3\%) were teachers and a further seven (12.3\%) were doctors. Thus, a quarter of episodes of abusive sexual intercourse amongst this sample were perpetrated by professionals.

Madu and Peltzer (2001) examined the child sexual abuse experiences of 414 secondary school students. Sixty-five instances of oral, anal or vaginal intercourse, or placing of fingers or objects in participants' anus or vagina are noted. Of these 65 cases, one (1.5\%) was perpetrated by a doctor and four (6.2\%) by 'other professionals' (not specified).

These recent findings must surely be a matter of concern for child protection professionals and authorities in South Africa.

\section{Common social fictions}

A widespread explanation for child sexual abuse in sub-Saharan Africa is the belief that intercourse with a virgin or young girl may have cleansing or curative powers and may act as a cure for HIV and other sexually transmitted diseases. This belief has its parallels in $19^{\text {th }}$ century Europe, when it was thought that venereal diseases could be cured "by means of sexual intercourse with children" (de Mause, 1974, p. 49). Similarly, Weinburg $\left(1955\right.$, cited in Renvoize, 1993) reports that there were groups in $20^{\text {th }}$ century America who still believed that, just as one can catch venereal disease from an infected partner, so one can also 'catch' purity and cure such infection by having intercourse with one's pre-pubertal daughter. 
While the practice of 'curing' oneself of AIDS by having sex with a virgin or young girl is commonly reported in the literature, there is little scientific evidence to indicate how widespread, or not, this practice is in sub-Saharan Africa.

Common trajectories of discovery

Contemporary awareness of the abuse and neglect of children is typically dated to Kempe, Silverman, Steele, Droegmueller, and Silver, H.K. (1962) and the seminal work on the 'battered baby syndrome' carried out in Denver, Colorado. This was followed in later years by an increasing awareness, first among professionals, and then amongst the wider public, of the sexual abuse of children, with most Englishspeaking Western societies heavily influenced by developments and changes in knowledge, policy and practice in the United States (Parton, 2002). In Ireland, for instance, the Department of Health was concerned only with physical injuries to children during the 1970s. The first brief reference to sexual abuse in Department of Health policy and practice documents was in 1983 (Department of Health, 1983). Only in the 1987 Child Abuse Guidelines: Guidelines on Procedures for the Identification, Investigation and Management of Child Abuse was the sexual abuse of children specifically identified as a separate issue to that of physical abuse, or "non-accidental injury" (Department of Health, 1987). Only in 2002 was the first national study of the prevalence of child sexual abuse amongst the general population published in Ireland (McGee et al., 2002).

This trajectory of discovery can also be observed in South Africa, where an initial 'discovery' of child sexual abuse in the United States in the 1970s was followed by a similar 'discovery' in South Africa 15 to 20 years later (for example, Westcott, 1984; Jaffe \& Roux, 1988; Haffejee, 1991). Outside of South Africa, it is only in the last five years that other countries in sub-Saharan Africa have begun to address the problem of child sexual abuse in their practice and professional literature [for example, Meursing et al., 1995 (Zimbabwe); Armstrong, 1998 (Zimbabwe); Lema, 1997 (Malawi)]. Similarly, wider public awareness, as reflected in newspaper coverage of the issues, has appeared only in the last few years. 


\section{CONCLUSION}

Clinical studies on child sexual abuse in sub-Saharan Africa come predominantly from South Africa. They illustrate that child sexual abuse (typically perpetrated by family members or others known to the child) occurs amongst all ethnic groups. Studies which use larger samples (typically, university students) are reported exclusively from South Africa. The results show that childhood experiences of unwanted sexual touching are reported at rates from 5.2\% (Madu, 2001) to 26.3\% (Collings, 1997) (the divergence most likely being due to differing operationalisations of child sexual abuse; in this instance, 'touched sexually by force' compared to 'unwanted genital fondling', respectively). Rates for childhood experiences of abusive sexual intercourse are less divergent; $7.5 \%$ for 'rape and attempted rape' (Levett, 1989), 5.8\% for 'sexual intercourse' (Collings, 1997), 3.86\% for 'sexual intercourse by force' (Madu \& Peltzer, 2000; 2001), and $4.5 \%$ for 'oral/anal/vaginal intercourse by force' (Madu, 2001).

Regarding the causes of child sexual abuse in sub-Saharan Africa, three explanations are dominant. Firstly, the disintegration of clan authority and exposure to the harmful elements of modernity, due to rapid social change. It is widely believed, throughout the region, that there has been a dramatic and sudden increase in child sexual abuse in recent years. However, no comparative empirical data exist to substantiate (or refute) these perceptions. Secondly, intercourse with young girls is reported to be a common 'cure' for sexually transmitted diseases, including HIV/AIDS. This, it is suggested, may explain some of the incidence of child sexual abuse. Furthermore, young girls may be desirable as sexual partners as men may reason that they are less likely to be infected with HIV. Whilst this explanation may have some validity, this issue has yet to be adequately investigated. Thirdly, explanations for the sexual abuse of children are sought in the male-dominated nature of society, particularly, common perceptions of the 'uncontrollability' of male sexual urges and views on the role of physical force in sexual relations. A number of authors refer to the African child's socialisation for obedience and acquiescence as a vulnerability factor for sexual abuse.

To conclude, insufficient data exist on the nature and incidence of child sexual abuse in SSA. Research has been largely confined to Southern Africa. The current focus at NGO and UN agency level on commercial 
sexual exploitation of children (CSEC) and its relationship with widespread poverty is welcome. However, the challenges of recognising child sexual abuse in homes and communities must also be faced by the governments of SSA. This is particularly so given the potential in the region for deadly STDs being spread by the sexual abuse of children. Base-line epidemiological data are required on the nature and incidence of child sexual abuse in SSA to identify target areas for intervention.

Table 1: Type of contact sexual abuse amongst a sample of 640 South African female university students

\begin{tabular}{|c|c|c|}
\hline & $\begin{array}{c}\text { Respondents reporting abuse } \\
(\mathbf{n = 2 2 3}) \\
\mathbf{\%}\end{array}$ & $\begin{array}{c}\text { Total sample } \\
(\mathbf{N}=\mathbf{6 4 0}) \\
\mathbf{\%}\end{array}$ \\
\hline Genital fondling & 62.2 & 26.3 \\
\hline Sexual intercourse & 13.7 & 5.8 \\
\hline Attempted intercourse & 7.8 & 3.3 \\
\hline Oral sex & 5.6 & 2.3 \\
\hline 'Other' & 10.7 & 4.5 \\
\hline Total & 100 & 34.8 \\
\hline
\end{tabular}

Source: Collings (1997). 
Table 2: Contact sexual abuse, by ethnicity, reported by South African secondary students

\begin{tabular}{|c|c|c|c|}
\hline & $\begin{array}{c}\text { Sample, by } \\
\text { ethnicity }\end{array}$ & $\begin{array}{c}\text { Number reporting } \\
\text { contact sexual abuse, } \\
\text { by ethnicity }\end{array}$ & $\begin{array}{c}\text { Percentage reporting } \\
\text { contact sexual abuse, } \\
\text { by ethnicity }\end{array}$ \\
\hline Blacks & 336 & 172 & 51.2 \\
\hline Whites & 51 & 39 & 76.5 \\
\hline Coloured & 10 & 9 & 90 \\
\hline Other & 11 & 4 & 36.4 \\
\hline $\begin{array}{c}\text { 'No response' (did not } \\
\text { indicate skin colour) }\end{array}$ & 6 & 1 & 17 \\
\hline
\end{tabular}

Source: Madu \& Peltzer (2000). 
Table 3: Cross-study comparison of prevalence of child sexual abuse in South Africa

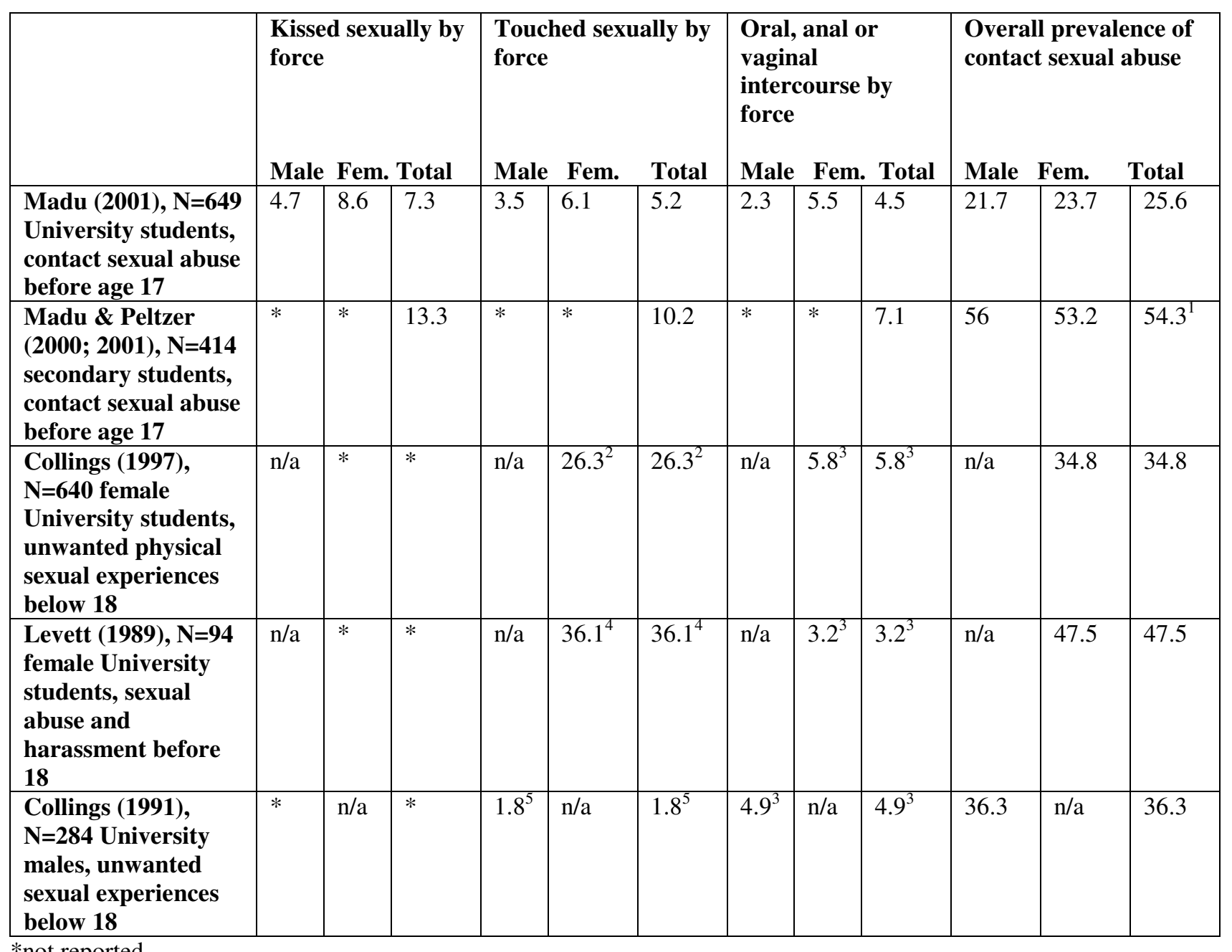

*not reported

${ }^{1}$ High prevalence rates here are probably because the definition employed in this study did not specify 'by force.' Rather, sexual abuse was defined as experiences with an adult or person at least five years older, before the age of 17

${ }^{2}$ unwanted genital fondling

${ }^{3}$ unwanted sexual intercourse

${ }_{5}^{4}$ kissed, stroked or touched intrusively (on genitals, buttocks or breasts) in a sexual way against your will ${ }^{5}$ unwanted sexual touching/kissing 
Table 4: Reported rape cases at seven major Bulawayo police stations by age group of victim, selected years

\begin{tabular}{|c|c|c|c|c|}
\hline $\begin{array}{c}\text { Age group } \\
\text { (years })\end{array}$ & $\mathbf{1 9 8 5}(\mathbf{n = 1 0 6})$ & $\mathbf{1 9 8 8}(\mathbf{n}=\mathbf{1 5 0})$ & $\mathbf{1 9 9 1}(\mathbf{n = 2 1 5})$ & Total, 1985-1991 (n=1025) \\
\hline $\mathbf{\%}$ & $\mathbf{\%}$ & $\mathbf{\%}$ & $\mathbf{\%}$ \\
$\mathbf{1 2 - 1 5}$ & 20 & 8 & 15 & 14 \\
$\geq \mathbf{1 6}$ & 20 & 27 & 26 & 24 \\
\hline
\end{tabular}

Source: Meursing et al. (1995). 
Table 5: Estimates of proportion of all children in various countries who have experienced penetrative sexual abuse with an Aids/HIV infected person

\begin{tabular}{|c|c|c|c|}
\hline & $\begin{array}{c}\text { Estimated } \\
\text { prevalence of } \\
\text { penetrative sexual } \\
\text { abuse during } \\
\text { childhood } \\
(\boldsymbol{\%})\end{array}$ & $\begin{array}{c}\text { Estimated incidence } \\
\text { of Aids/HIV among } \\
\mathbf{1 5 - 4 9} \text { year olds }\end{array}$ & $\begin{array}{c}\text { Estimates of proportion of } \text { all } \\
\text { children who have experienced } \\
\text { penetrative sexual abuse with } \\
\text { an Aids/HIV infected person }\end{array}$ \\
\hline Mozambique & 5 & $(\boldsymbol{\%})$ & $(\boldsymbol{\%})$ \\
\hline South Africa & 5 & 13.22 & 0.66 \\
\hline Zambia & 5 & 19.94 & 0.99 \\
\hline Zimbabwe & 5 & 19.95 & 0.99 \\
\hline Botswana & 5 & 25.06 & 1.25 \\
\hline Ireland & 4.13 & 35.8 & 1.79 \\
\hline
\end{tabular}




\section{BIBLIOGRAPHY}

Argent, A.C., Bass, D.H., \& Lachman, P.I. (1995). Child abuse services at a children's hospital in Cape Town, South Africa. Child Abuse \& Neglect, 19(11), 1313-1321.

Armstrong, A. (1998). Consent and compensation: the sexual abuse of girls in Zimbabwe. In W. Ncube (Ed.), Law, culture, tradition and children's rights in Eastern and Southern Africa (pp. 129-149). Aldershot: Ashgate Dartmouth.

Badgley, R., Allard, H., McCormick, N., Proudfoot, P., Fortin, D., Ogilvie, D., Rae-Grant, Q., Gelinas, P., Pepin, L., \& Sutherland, S. (1984). Sexual offenses against children (Vol. 1). Ottawa: Canadian Government Publishing Centre.

Barker, G., \& Rich, S. (1992). Influences on adolescent sexuality in Nigeria and Kenya: findings from recent focus group discussions. Studies in Family Planning, 23(3), 199-210.

Bergner, R.M., Delgardo, L.K., \& Graybill, D. (1994). Finkelhor's risk factor checklist: a cross-validation study. Child Abuse \& Neglect, 18, 331-340.

Borongo, L.R, Borgdorff, M.W., Mosha, F.F., Nicoll, A., Grosskurth, H., Senkoro, K.P., Newell, J.N., Changalucha, J., Klokke, A.H., Killewo, J.Z., Velema, J.P., Hayes, R.J., Dunn, D.T., Muller, L.A.S., \& Rugemalila, J.B. (1992). The epidemiology of HIV-1 infection in urban areas, roadside settlements, and rural villages in Mwanza, Tanzania. Aids, 6(12), 1521-1528.

Briere, J., \& Runtz, M. (1985). Symptomatology associated with prior sexual abuse in a non-clinical sample. Paper presented at the annual meeting of the American Psychological Association, Los Angeles. 
Buzzard, S.A. (1982). Women's status and wage employment in Kisumu, Kenya. The American University, Washington: Ph.D. thesis.

Calvès, A., Cornwell, G., \& Enyegue, P. (1996). Adolescent sexual activity in sub-Saharan Africa: do men have the same strategies and motivations as women? Working paper AD96-04 of the Population Research Institute, Pennsylvania State University.

Caraël, M. (1995). Sexual behavior. In J. Cleland \& B. Ferry (Eds.). Sexual behavior and Aids in the Developing World. London: Taylor and Francis.

Collings, S.J. (1991). Childhood sexual abuse in a sample of South African university males: prevalence and risk factors. South African Journal of Psychology, 21 (3), 153-158.

Collings, S.J. (1997). Child sexual abuse in a sample of South African women students: prevalence, characteristics, and long-term effects. South African Journal of Psychology, 27(1), 37-42.

de Mause, L. (1974). The history of childhood. New York: Psychohistory Press.

Department of Health (1983). Non-accidental Injury to Children. Guidelines on Procedures for the Identification and Management of Non-Accidental Injury to Children. Dublin: Department of Health.

Department of Health (1987). Child Abuse Guidelines: Guidelines on Procedures for the Identification, Investigation and Management of Child Abuse. Dublin: Department of Health.

Emmaneul, L.A. (1975). Diseases of the genitalia in girls from birth to menarche. Nigerian Medical Journal, 5, 131-133. 
Ennew, J., Gopal, K., Heeran, J., \& Montgomery, H. (1996). Children and prostitution: how can we measure and monitor the commercial sexual exploitation of children? Literature review and annotated bibliography. Oslo: Childwatch International and Centre for Family Research, Cambridge University. http://www.childwatch.uio.no/cwi/projects/indicators/prostitution

Finkelhor, D. (1979). Sexually victimized children. New York: Free Press.

Finkelhor, D. (1994). The international epidemiology of child sexual abuse. Child Abuse and Neglect, 18(5), 409-417.

Fraser, G., \& Kilbride, P. (1980). Child abuse and neglect - rare, but perhaps increasing, phenomenon among the Samia of Kenya. Child Abuse \& Neglect, 4, 227-232.

Gueye, A-K. (1995). Bibliographie annoté sur l'enfance. Dakar: CODESRIA.

Haffejee, I.E. (1991). Sexual abuse of Indian (Asian) children in South Africa: first report in a community undergoing cultural change. Child Abuse \& Neglect, 15, 147-151.

Human Rights Watch (2001). Scared at school: sexual violence against girls in South Africa. New York: Human Rights Watch.

International Labour Organisation/International Programme for the Elimination of Child Labour (2001). Tanzania. Children in prostitution: a rapid assessment. Geneva: ILO.

Jaffe, A.M., \& Roux, P. (1988). Sexual abuse of children - a hospital based study. South African Medical Journal, 74, 65-67. 
Jinadu, M. (1986). Combating child abuse and neglect in developing and newly industrializing countries: a unique primary health care approach. Child Abuse \& Neglect, 10, 115-120.

Kaboberi-Macharia, J. (1998). Reconstructing the image of the girl-child. In W. Ncube (Ed.), Law, culture, tradition and children's rights in Eastern and Southern Africa (pp. 47-56).. Aldershot: Ashgate Dartmouth.

Kempe, C. H., Silverman, F.N., Steele, B.F., Droegmueller, W., \& Silver, H.K. (1962). The battered child syndrome. Journal of the American Medical Association, 181, 17-24.

Kisekka, M.N., \& Otesanya, B. (1988). Sexually transmitted diseases as a gender issue: examples from Nigeria and Uganda. Paper given at the AFARD/AAWORD Third General Assembly and Seminar on The African Crisis and the Women's Vision of the Way Out, Dakar, August 1988.

Korbin, J.E. (1987). Child sexual abuse: Implications from the cross-cultural record. In N. ScheperHughes (Ed.), Child survival: Anthropological perspectives on the treatment and maltreatment of children (pp. 247-265). Dordrecht, Holland: D. Riedel Publishing Company.

Korbin, J. (1991). Cross-cultural perspectives and research directions for the $21^{\text {st }}$ century. Child Abuse \& Neglect, 15, Sup. 1, 67-77.

Lachman, P. (1996). Child protection in Africa: the road ahead. Child Abuse \& Neglect, 20(7), 543-547.

Lalor, K. (2001). Child sexual abuse in Ireland: a brief history and examination of research. In K. Lalor (Ed.), The end of innocence: child sexual abuse in Ireland, (pp. 1-26). Dublin: Oak Tree Press.

Larsen, J.V., Chapman, J.A., \& Armstrong, A. (1998). Child sexual abuse in KwaZulu-Natal, South Africa. Transactions of the Royal Society of Tropical Medicine and Hygiene, 92, 262-264. 
Lascaratos, J., \& Poulakou-Rebelakou, E. (2000). Child sexual abuse: historical cases in the Byzantine empire (324-1453 AD). Child Abuse \& Neglect, 24(8), 1085-1090.

Lema, V.M. (1997). Sexual abuse of minors: emerging medical and social problem in Malawi. East African Medical Journal, 74(11), 743-746.

Levett, A. (1989). A study of childhood sexual abuse among South African university women students. South African Journal of Psychology, 19 (3), 122-129.

LeVine, S., \& LeVine, R. (1981). Child abuse and neglect in sub-Saharan Africa. In J. Korbin (Ed.), Child abuse and neglect: cross-cultural perspectives (pp. 35-55). Berkeley, CA: University of California Press.

LeVine, S., \& LeVine, R. (1985). Age, gender and the demographic transition: the life course in agrarian societies. In A. Rossi (Ed.), Gender and the life course (pp. 29-42). New York: Aldine.

Loening, W. (1981). Child abuse among the Zulus: a people in cultural transition. Child Abuse \& Neglect, 5, 3-7.

Madu, S.N. (2001). The prevalence and patterns of childhood sexual abuse and victim-perpetrator relationships among a sample of university students. South African Journal of Psychology, 31(4), 32-37.

Madu, S.N., \& Peltzer, K. (2000). Risk factors and child sexual abuse among secondary school students in the Northern Province (South Africa). Child Abuse \& Neglect, 24(2), 259-268. 
Madu, S.N., \& Peltzer, K. (2001). Prevalence and patterns of child sexual abuse and victim-perpetrator relationship among secondary school students in the Northern Province (South Africa). Archives of Sexual Behaviour, 30(3), 311-321.

Martin, J.L. (1994). CSA findings from a community sample of New Zealand women: prevalence, risks and outcomes. Paper presented at the Tenth International Congress on Child Abuse and Neglect, Kuala Lumpur, Malaysia.

McGee, H., Garavan, R., de Barra, M., Byrne, J., \& Conroy, R. (2002). The SAVI Report: Sexual abuse and violence in Ireland - a national study of Irish experiences, beliefs and attitudes concerning sexual violence. Dublin: The Liffey Press \& Dublin Rape Crisis Centre.

Mensch, B.S., Bruce, J., \& Greene, M.E. (1998). The uncharted passage: girls' adolescence in the developing world. New York: Population Council.

Meursing, K., Vos, T., Coutinho, O., Moyo, M., Mpofu, S., Oneko, O., Mundy, V., Dube, S., Mahlangu, T., \& Sibindi, F. (1995). Child sexual abuse in Matabeleland, Zimbabwe. Social Sciences and Medicine, 41(12), 1693-1704.

Mgalla, Z., Schapink, D., \& Boerma, J. (1998). Protecting schoolgirls against sexual exploitation: a guardian programme in Mwanza, Tanzania. Reproductive Health Matters, 6(12), 19-30.

Muntabhorn, V. (1992). Sale of Children. Report submitted by the Special Rapporteur on the sale of children. New York: United Nations (E/CN.4/1992/55).

National Council for Population and Development (NCPD), Central Bureau of Statistics (CBS) (Office of the Vice President and Ministry of Planning and National Development) [Kenya], and Macro 
International (MI) (1999). Kenya Demographic and Health Survey 1998. Calverton, Maryland: NDPD, CBS and MI.

Nelson, N. (1987). Selling her kiosk: Kikuyo notions of sexuality and sex for sale in Mathare Valley, Kenya. In P. Caplan (Ed.), The cultural construction of sexuality. London: Tavistock.

Nunn, A.J., Kengeya-Kayondo, J.F., Malamba, S.S., Seeley, J.A., \& Mulder, D.W. (1994). Risk factors of HIV-1 infection in adults in a rural Ugandan community: a population study. Aids, 8(1), 81-86.

Okeahialam, T. (1984). Child abuse in Nigeria. Child Abuse \& Neglect, 8, 69-73.

Parton, N. (2002). Protecting children: a socio-historical analysis. In K. Wilson \& A. James (Eds.). The child protection handbook. Baillière Tindall: Edinburgh.

Renvoize, J. (1993). Innocence destroyed: a study of child sexual abuse. London: Routledge.

Ritchie, J., \& Ritchie, J. (1981). Child rearing and child abuse: the Polynesian context. In J. Korbin (Ed.), Child abuse and neglect: cross-cultural perspectives (pp. 186-204). Berkeley, CA: University of California Press.

Ross, F. (1995). Annotated bibliography on childhood: outline, general findings and research recommendations. Dakar: CODESRIA.

Russell, D. (1986). The secret trauma: incest in the lives of girls and women. New York: Basic Books.

Standing, H., \& Kisekka, M. N. (1989). Sexual behaviour in sub-Saharan Africa: a review and annotated bibliography. London: Report to the Overseas Development Administration. 
UNAIDS/WHO (2000). Epidemiological fact sheets on HIV/AIDS and sexually transmitted infections.

www.unaids.org/hivaids/info/statistics (accessed 26/5/'02).

UNHCR \& SC-UK (2002). Notes for implementing and operational partners by UNHCR and Save the Children-UK on sexual violence and exploitation: the experience of refugee children in Guinea, Liberia and Sierra Leone based on initial findings and recommendations from Assessment Mission 22 October-30 November 2001. Geneva: UNHCR \& SC-UK

Unicef (1999). Children in need of special protection measures: a Tanzanian study. Dar es Salaam: Unicef.

Unicef \& ANNPCAN (2001). Analysis of the situation of sexual exploitation of children in the Eastern and Southern Africa region. $\underline{\text { www.focalpointngo.org/yokohama/latestnews/CSECEastSouthernAfricaDraft }}$

Weinburg, S. K. (1955). Incest behavior. New York: Citadel.

Westcott, D. (1984). Sexual abuse of children. South African Medical Journal, 65(2), 895-897. 